\title{
Why are rural Indian women so thin? Findings from a village in Maharashtra
}

\author{
GP Chorghade ${ }^{1}$, M Barker $^{1}$ *, S Kanade Ka $^{2}$ and CHD Fall ${ }^{1}$ \\ ${ }^{1}$ MRC Epidemiology Resource Centre, Southampton General Hospital, Southampton SO 166 YD, UK: ${ }^{2}$ KEM Hospital \\ Research Centre, TDH Building - 3rd Floor, Rasta Peth, Pune - 411011 , Maharashtra, India
}

Submitted 11 January 2005: Accepted 18 May 2005

\begin{abstract}
Objective: To identify social, behavioural and cultural factors that explain the thinness of young women relative to their men in rural Maharashtra, India.

Design: Twelve focus group discussions were conducted to explore the villagers' understanding of why women in their area might be thinner than men.

Setting: Pabal village and surrounding hamlets, in the Pune district of Maharashtra, India.

Subjects: Samples of young mothers and fathers, grandmothers and grandfathers were selected from families in the village with children below 10 years of age.

Results: Four factors were identified that the villagers felt contributed to the disparity in thinness. First, marriage isolated girls from their own families and villages, and brought the expectation of early motherhood. Young brides were often unable to relax and eat adequately. Second, marriage increased the workload of young women. They were expected to do the heaviest household chores as well as farm work in this predominantly agricultural community. Third, women had no financial autonomy or freedom of movement, and were therefore denied access to supplementary food sources available to men. Fourth, young women felt responsible for their household's health and success. They were encouraged to fast regularly to ensure this. Despite feeling responsible, young women had no control over factors that might affect the household's well being. This made them anxious and worried a great deal of the time. Conclusions: Interventions to improve the nutritional status of young women in this region need to recognise the roles and responsibilities taken up by young brides.
\end{abstract}

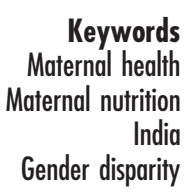

A higher percentage of babies is born with low birth weight $(<2500 \mathrm{~g})$ on the Indian subcontinent than anywhere else in the world ${ }^{1}$. Low-birth-weight babies are four times more likely to die in the first month of life than are normal-birth-weight babies ${ }^{2}$. They are also at greater risk of developing cardiovascular disease and type 2 diabetes in later life ${ }^{3}$. Factors known to contribute to low birth weight are short maternal stature as a result of undernutrition and infections during childhood, and poor nutrition before conception and during pregnancy ${ }^{4}$.

Although a poor country, India has a higher gross national product than many other developing countries and has shown remarkable economic growth in recent years. However, it performs poorly on indicators of maternal size and birth weight ${ }^{1}$. A World Health Organization study showed that, compared with other Asian countries, Indian women have the lowest heights and weights ${ }^{5}$. There are clearly factors in India that prejudice the nutritional status of women beyond simply poverty.

Between June 1994 and April 1996, a study of the nutritional status of women living in villages near Pune city in western India - The Pune Maternal Nutrition Study - was carried out. It was designed to examine the relationship of maternal nutrition, both prior to conception and during pregnancy, with foetal growth ${ }^{6-8}$. The body weights and heights of married women of reproductive age and of their husbands were measured. The study indicated that the thinner women had thinner babies, but also found the women to be significantly thinner than their husbands (Table 1).

Gender disparity in India is well documented and widely debated. Indian society is traditionally patriarchal. Inheritance is through the male line, and the majority religion, Hinduism, specifies that a man must have a son if he is to achieve peace after death. Boy children are regarded as an asset because of their potential to contribute to family prosperity throughout their lives. Girls move away to live with their in-laws after marriage. The practice of paying a dowry upon marriage means that girls represent a net cost to a family ${ }^{9}$.

The combined effects of selective foeticide and the rapid increase in mortality in girl babies relative to boys after the first month of life ${ }^{10}$ mean that there are now only 
Table 1 Comparison of the body mass index (BMI) distribution of 580 women and 587 men aged 16 to 30 years who took part in the Pune Maternal Nutrition Study

\begin{tabular}{lrrrrr}
\hline & \multicolumn{2}{c}{ Women } & & \multicolumn{2}{c}{ Men } \\
\cline { 2 - 3 } \cline { 6 - 6 } BMI $\left(\mathrm{kg} \mathrm{m}^{-2}\right)$ & $n$ & $\%$ & & $n$ & $\%$ \\
\hline$\leq 15.99$ & 66 & 11.2 & & 16 & 2.7 \\
$16.00-16.99$ & 111 & 20.1 & & 64 & 10.9 \\
$17.00-18.49$ & 200 & 34.1 & & 151 & 25.7 \\
$18.50-24.99$ & 202 & 34.4 & & 335 & 57.1 \\
$\geq 25.00$ & 1 & 0.2 & & 21 & 3.6 \\
Total & 580 & 100.0 & & 587 & 100.0 \\
\hline
\end{tabular}

927 Indian girls aged 6 years or less for every 1000 boys $^{11}$. Girl babies are more likely to suffer from malnutrition ${ }^{12}$, and are breast-fed for a shorter time ${ }^{13}$. Differences in the speed with which health care is sought for, and the amount of money that is spent on, boys and girls have been identified as ways in which girls' health might be prejudiced $^{14-16}$.

The traditional pattern of food allocation in Hindu households is that women eat only after the men have finished, and a young wife must allow her mother-in-law to eat first ${ }^{17}$. Despite receiving the smallest and worst share of the food, young rural women have high daily energy expenditure ${ }^{18}$, and will often continue to work throughout pregnancy.

These observations suggest that the way society is organised in India may directly affect the nutritional status of Indian women. Studies of health-care provision and women's autonomy have pointed out that women in rural communities may be particularly disadvantaged ${ }^{16,19}$. However, it is not clear how these cultural factors are manifested, or by what mechanisms these biases result in differences in nutritional status. The present study set out to investigate why the women in a village in rural Maharashtra were thinner than the men by asking villagers for their explanations.

\section{Methods and procedures}

Focus group discussions were held throughout the spring and summer of 1998 in the largest of the Pune Maternal Nutrition Study villages, Pabal. Most families in the area live by farming cash crops (millet, sorghum, groundnuts and onions), and women work on the farms as well as at home, doing domestic work and carrying heavy loads of water and firewood. Few are educated beyond primary school level. Twelve focus group discussions were held in Pabal and surrounding hamlets: three with young mothers (Bhorshet, Bargad Wasti, Pirachamalla), three with young fathers (Futanwadi, Pimplewadi, Thapewadi), three with grandmothers (Narhebend, Pimplewadi, Zodakwadi) and three with grandfathers (Central Pabal, Agarkarwadi, Ganesh Nagar). The number of discussion groups was limited by the convention that no more discussions need to be undertaken when responses begin to recur. The focus groups were held in local balwadi or preschools and in people's homes.

Focus group discussions are a well-established method of getting participants' understanding of and perspectives on certain issues ${ }^{20}$. They usually constitute a group of six to eight people, selected for their homogeneity on some factor important to the research, such as age or sex. Discussions are 'focused' on the topic of interest to the researcher. A team consisting of a community health worker, a moderator (G.P.C.) and an observer (S.K.) were involved in conducting these discussions. They were trained to conduct the focus groups in a standardised way and discussions were tape-recorded.

In preparation for the focus group discussions, a question route was developed. This lists the questions around which the discussion will focus and the order in which they will be asked. The specific questions were derived from a review of the literature, discussions with nutritionists, epidemiologists and social scientists in the field, and from the results of pilot focus group discussions held in two different villages. The five broad areas of inquiry were:

- The family structure, hierarchy and decision-making within the household;

- How health care was sought and provided for the children in the family;

- Changes in young women's diet and workload after marriage, and how families select daughters-in-law;

- Fasting patterns and differences in fasting between men and women;

- Explanations for the thinness of young women, whether the community identifies this as a problem, and, if so, how it can be overcome.

\section{Selection of participants}

To encourage free discussion, separate groups of grandfathers, grandmothers, young fathers and young mothers were created. Heterogeneous groups containing for example a mixture of mothers-in-law and daughters-inlaw might inhibit the younger women from expressing themselves freely. Participants were selected from grandparents or parents of children aged 10 years or less.

\section{Analysis}

Tapes were transcribed on the day after the discussion, using the notes taken by the observer to supplement the tape recordings, especially when more than one person had spoken at the same time. The Marathi script was translated into English, and each transcript coded into categories that related to each of the issues on the question route. Comments from participants that did not relate to these five issues were grouped into categories 
that reflected their content. Separate documents were produced containing the comments of the young mothers, the young fathers, the grandmothers and the grandfathers in response to each question raised in the discussions. It was easier to collate the viewpoints of the four different groups separately ${ }^{21}$. These documents were read independently by two of the researchers (G.P.C. and M.B.), who agreed an interpretation. Finally, four factors emerged that the villagers felt contributed to the disparity in nutritional status between young men and women. These did not correspond exactly to the five areas of inquiry, but emerged from consideration of the discussions as a whole. Results are presented accordingly.

\section{Findings and interpretation}

\section{Marriage and early motberbood}

The increasing cost of getting daughters married meant that parents of young women perceived them to be a burden on the family finances. Parents were often forced to take out loans to fund the wedding ceremony and dowry. One grandmother said:

'Because of the dowry system everyone wants only sons. Daughters are a burden.' (Grandmother, Narhebend)

Grandparents said that 'dowry' was a recent phenomenon in this area. In the past 'bride price' had been the dominant tradition. These two cultural phenomena have different origins and consequences. In the 'bride price' system the groom pays cash or kind to the bride's parents for taking the girl to his home, while the dowry system dictates that the bride's family gives cash and gifts to their future in-laws and bears the cost of the wedding. The implication of the latter is that the groom's family is paid to support the bride, whereas in the former the groom's family compensates the bride's family for her loss. In the first she is a commodity of value, in the second she represents a burden.

The villagers attributed the rise of dowry to two factors. Girls were now being educated and wanted educated grooms, but demand had outstripped supply and families with girls had to pay for their daughters to marry educated boys.

The more educated the girl was, the bigger her dowry would have to be to attract a boy of equal or greater education:

If the girl is educated then she looks forward to marrying an educated boy, and an educated boy takes more dowry.'

(Father, Futanwadi)

Parents were also concerned for the comfort of their daughters, and wanted them to marry educated boys so they could escape agricultural labour. Families who owned irrigated land, or whose son was a factory or business employee, could also demand a larger dowry. Tambiah studied bride-wealth and dowry practices amongst Hindus of north India, and found these families also to give a larger dowry when they marry their daughters into nonagricultural families ${ }^{22}$. As in our study, this was done to secure their daughters' comfort. The outcome of the practice of dowry is that girls represent a net cost to the family and are therefore less desirable than boys.

Unmarried girls represent another problem for their families. Marriage in India is illegal before the age of 18 years. However, men who took part in the focus groups felt that they had to marry their daughters earlier to protect their family name. The fathers believed that increased access to television was teaching their children about sex earlier than in the past. This might lead them to have sex and get pregnant before marriage, which would bring disgrace upon the family:

'When boys and girls are growing up in village areas it is better to get your daughter married soon as it does not spoil the family name, as it would if she got pregnant.' (Father, Thapewadi)

Historically, women in India have married very young, sometimes as soon as they achieved menarche. There is evidence that, although the age of Indian brides has risen in the last 100 years, many still marry at ages younger than the minimum set by law. The National Family Health Survey, India, 1992-1993 found 39\% of women to have married between the ages of 15 and 19 years with a median age of 16 years $^{13}$. Twice as many rural adolescent girls were married as urban girls. The fathers' concerns about preserving their daughters' purity and thus the family name might explain why the tendency for early marriage persists. This phenomenon has been described elsewhere in India $^{23}$.

Despite these issues, the villagers insisted that they loved and valued their daughters. However, all groups, particularly the fathers, clearly expressed and justified their desire for sons:

'There is no difference in treatment of a son and a daughter. Though everyone does want a son.'

Moderator: 'Why does everyone want a son?'

'For the sake of inheritance.'

'He will take care of father's farm and family, and perform the funeral rites as they have to be done by a son. Girls go to the husband's home and the name of the father vanishes, whereas with a son the father's name continues.'

'Also, the son-in-law will have no affinity for our land and most likely be will sell it. No one will even remember a man if he has no son.'

'The son takes care of his parents in old age. The daughters will remain in the in-laws' home.'

Moderator: 'Then do people favour sons over daughters?' It is not like that. If one has three girls and then a boy, one 
tends to treat him to whatever he wants but one does not start hating the girls.' (Fathers, Pimplewadi)

Though villagers were aware of the health problems for women having babies very young, there was obvious social pressure on couples to prove their fertility by producing a baby in the first year of marriage:

Nowadays, within a year of marriage, one tends to have a child. It is common to see the elder child of eleven months when the second one arrives. If they [young women] don't become thin in this way then what will they be?' (Grandmother, Pimplewadi)

This expectation is widely held in India ${ }^{24}$, and there is a social stigma attached to being childless. Pressure to become pregnant during the first year of marriage and to conceive again quickly following the birth of a girl may come from the woman herself, since bearing sons is a way to acquire social status ${ }^{19}$. The young bride can 'prove' herself to her new family by having a child, and some of the pressure is lifted:

'She gets pressured by the family and when she has had a child she no longer feels so scared.' (Father, Thapewadi)

It was widely felt that women should not reduce their workload during pregnancy. Older women in the focus groups advised their daughters-in-law to work throughout pregnancy because they believed it led to an easier delivery:

\section{'More work helps an easy delivery as there are fewer complications and pains.'}

'Work helps the veins to get loose and the body is able to relax better during labour.' (Grandmothers, Narhebend)

The Pune Maternal Nutrition Study showed that there is little reduction in the workload of these women in pregnancy ${ }^{25}$. Women who worked harder in early and mid gestation produced babies who were smaller, thinner and had smaller heads ${ }^{25}$.

From the women's point of view, small babies may be more desirable. The women in the villages had mixed views as to whether a big or a small baby was more desirable, but they believed big babies to cause problems during delivery and that eating more during pregnancy led to smaller babies:

'Eating less helps in giving birth to a larger baby, women who eat more have smaller babies.' (Grandmother, Narhebend)

'Eat well, because if you do not eat well then the child will be big and give trouble during the delivery.' (Grandmother, Pimplewadi)

\section{Work}

Work occupied the great majority of women's time. All the participants agreed that the women of the house worked the hardest. The young women worked both at home and on the farm:

'Women work hard, they do a lot of housework. Then wake up early, fill up water, and go to the farm. When at home, they are always doing something or the other.' (Grandfather, Central Pabal)

'They cook, do farm activities, work all day.' (Father, Thapewadi)

Some husbands said that they occasionally helped by bringing water from the well when their wives had too many chores. Both men and women acknowledged that young women had less time to eat than other family members and were sometimes too tired to eat:

'When my husband leaves for the farm and I am still finishing the household work in a hurry, I tend to eat half a bhakri" instead of one so that I can catch him [husband] up at the farm for work.' (Mother, Bargadwasti)

'When she works too much, her body aches. Then how can she eat well? Food does not go in the stomach.' (Grandmother, Narhebend)

'They work a lot and do not eat on time and then fall sick.' (Father, Pimplewadi)

Some men thought that cooking the food and drinking too much tea were the cause of women's diminished appetite:

'Women drink a lot of tea and then eat less bhakri.'

'When a woman is cooking food, she makes herself a cup of tea. This tea suppresses her appetite and then she does not feel like eating food.' (Fathers, Futanwadi)

There was a consensus that women worked harder than men and that this was a major cause of women's thinness. Batliwala's study in south India also found that when women's field and domestic labour were both taken into account, women had higher daily energy expenditure than men in the same household ${ }^{18}$. However, this is not the way Indian women's work is perceived. National statistics show women to have lower labour force participation than in other developing and industrial countries. Their documented share of the adult labour force is only $31 \%$, compared with $42 \%$ in Bangladesh, $40 \%$ in Nepal and 43\% in Myanmar ${ }^{26}$. It seems likely that the official statistics underestimate unpaid labour. In an anthropological study in Uttar Pradesh, men claimed that women did not work as hard as they did, and that like children, women simply consumed food and contributed nothing economically ${ }^{27}$. The belief that women are thin because they work too hard is not universal.

Participants agreed that marriage initiated important changes in the working life of a woman. Although the amount of food available in her new home might be no

*The local bread made from ground millet. 
different, there was an increase in work for the young bride, who was expected to do the bulk of the household chores and work on the farm:

'The workload increases at the in-laws' home. One has to clean the clothes, utensils, collect water, clean the shed, and also cook. So the workload increases. Whereas at mother's home, one can do one sort of work and omit the other.'

'At mother's home there is less work. When she comes here [to the in-laws] she has to immediately take responsibility and do a lot of work.' (Mothers, Bargadwasti)

The anxieties experienced by young women on entering their new homes were understood by all participants:

'At her mother's home, if her mother tells her to do work she runs away to play. When her father tells her she just sits and does not listen. If her uncle tells her she answers back that she will not do this work. All this changes when she gets married. She gets anxious and does all the chores of filling water, cleaning the animal shed, cooking, taking care of animals. They feel scared of work.'

Moderator: 'Scared of work? Please explain?'

'Scared of their father-in-law, scared that he will say that she does not do any work and just sits at home.'

'No one really taunts the daughter-in-law, but she needs to do the work.' (Grandfathers, Ganesh Nagar)

'When you are new the amount you eat decreases as you are shy. If before you would eat "one" then in your new home you would eat "half".'

'When you are at your own parent's home you tend to be more relaxed and eat well.' (Mothers, Bargadwasti)

The new bride is a stranger in the village, reliant on her new family and subordinate to them. In her analysis of patriarchal systems around the developing world, Santow concluded that the newly married woman occupies the lowliest position in the traditional joint family ${ }^{28}$. The elder women assign work to the new bride.

A woman's ability to work hard was a major criterion for the selection of brides. Parents of sons looked for an ablebodied girl who was willing to do work on the farm and do the household chores:

'She should not be disabled and able to work on the farm.' (Grandfather, Central Pabal)

Moderator: 'If your son is working in a factory then why do you want a farming girl?'

'What happens when the company shuts down or when they visit us? They need to work on the farm.' (Grandfather, Agarkarwadi)

The participants believed that the growth of the dowry system reflected parents' desire to avoid placing their daughters in households where they would be expected to work so hard:
If the daughter marries into a "service" household where the groom has a job in a town or a city, then she has to only do the bousehold chores like cooking, washing but no farming. This means an easy lifestyle with enough sleep. In a farming household she has to work both on the farm and the house.'

'We take care that she leads a good life by giving dowry.' (Fathers, Pimplewadi)

'We feel that even if we have to spend Rs. 20000 then it is worth it, because our daughter will get happiness for life. And if we give her a farming boy then she has to take troubles all her life.' (Grandfather, Ganesh Nagar)

\section{Unequal access to resources}

It was clear from the focus group discussions that men made all the important household decisions and controlled the family's money. Some respondents felt that young women were incapable of taking important decisions:

'When we go out, women can only give water to the animals. They do not understand what is to be done outside.' (Grandfather, Agarkarwadi)

Women seldom or never had any money themselves, and whenever they needed anything they were expected to ask their men folk:

'Why do we need money? We do not go to the market or to the main village. If a vendor comes to the hamlet to sell sari then we might buy one.'

Moderator: 'Do women regularly get money to spend?'

No. Only children get money to buy sweets. We do service [work] on the farm and we do not need money to get there as we walk down to our workplace.'

Moderator: 'What do you do with the daily wage earned by you?' 'The money is given to the head of the household.' (Mother, Pirachamalla)

As the women said, they rarely went to the market and hence had no need for spending money. This meant that they were denied access to supplementary food sources. When men went to the village to the market or on business, they went to the snack shop and therefore had access to a more varied and micronutrient-rich diet than women:

'If we go to the main village the expense is on tea and breakfast.' (Grandfather, Agarkarwadi)

'One visit to the village costs Rs. 20. I have some snacks and buy tobacco.' (Father, Thapewadi)

'Men folk go to the main village, so end up eating more biscuits, and bhel*.' (Grandfather, Central Pabal)

Bhel is a snack rich in vitamin C and iron, and tea in the village would be served with milk and sugar. The men

* Bhel is a local snack made from fried gram flour noodles served with peas, onion, tomato, coriander and green chilli. 
described it as a social obligation to buy their friends a snack:

$$
\begin{aligned}
& \text { 'If one does not spend on food and tea for a relative or } \\
& \text { brother-in-law then be will feel that you are a miser. } \\
& \text { He will say that this fellow did not even offer tea. In the } \\
& \text { village, drinking tea is a valued thing.' (Grandfather, } \\
& \text { Ganesh Nagar) }
\end{aligned}
$$

Focus group participants recognised this as a significant factor in the better nutritional status of men. The men were also likely to have better access to food at home. Traditionally men and children eat first at family meals in this part of India. Women eat last, and only after the men and children have finished. Even where women receive the same number of calories as men, they are often denied micronutrient-rich foods like milk, fruit, treats and snacks $^{29}$.

The picture is one of young women's lack of autonomy. Women's lack of financial control is closely related to the restriction on their movements and has implications for their access to resources generally. Several authors have described the way in which restrictions on women's movements, combined with limited access to resources within the household, reduce their access to health care $^{14,30-32}$. Women's lack of autonomy is not just a problem for them but also affects the health of their children. Other studies have found that women are often excluded from decisions about whether to seek treatment for their sick children or relatives ${ }^{28}$.

When participants were asked about differences in the health care they provided for their children, they were emphatic that they treated sons and daughters equally:

'Same as sons, we do not believe in differences between sons and daughters.' (Grandmother, Narhebend)

'No it is not like that! Both are the same. One spends the same amount. Who says we do not spend on daughters?' (Grandfather, Ganesh Nagar)

'The son and daughter come from where? Isn't it the same place? [meaning the same womb] So they are the same. Then why should we differentiate?' (Grandmother, Zodakwadi)

Participants were distressed by the implication that they might love their daughters less than their sons. There was, however, a suggestion that when time and money were short, daughters might not receive their full share of attention:

'Both are equal. Sometimes one might not get time out of the daily routine and one might get a little delayed in taking her to the doctor.' (Father, Futanwadi)

'In homes where there are four daughters and one son, parents might fulfil all his [the son's] requirements. For example, he is "extra cared for", but when it comes to illness treatment there is no difference.'

Moderator: "What are the "extra cared for" things?'
'What ever he wants is given to him.'

'If you have one son, then whatever be asks for is given to bim.'

'Even if he ends up spoiling the thing, then parents will buy bim more.'

Moderator: 'What are the things the son wants?'

'Toys, sweets!' (Grandmothers, Zodakwadi)

Traditionally, decisions about seeking health care are taken by senior male members of the household, and medical treatment, like other precious resources, is allocated according to status.

The family structure affected the degree to which women felt they controlled their lives. They were aware of their powerlessness and wanted to be more involved in decision-making. The solution they identified was to be part of a nuclear family rather than the joint, extended family traditional in rural India:

'Today's women feel that even if they work hard in a joint family, no one appreciates it and the returns are not given to them.' (Grandmother, Zodakwadi)

The effect of moving to a nuclear family would be to make the woman and her husband heads of household. The benefits of having more say in family matters and more control over family finances outweighed for the women the extra work involved in running a nuclear family, with no sisters-in-law or mother-in-law to share domestic chores. The women felt they might have more chance to strengthen the bond with their husbands and thus exert more influence:

'Also a person progresses when in a nuclear family. He [her husband] gets more involved seriously when one becomes a nuclear family, as he plans what to grow, and thinks about irrigation problems.' (Mother, Bargadwasti)

'In a nuclear family one can actively take decisions about day-to-day functioning which cannot be done in a joint family.' (Mother, Bhorshet)

All except the young mothers favoured a joint family structure and it was clear that a move to a nuclear family would meet some resistance. Fathers felt that nuclear families put more responsibility on them:

Nuclear family life is difficult, as there is more responsibility, and more burden on the man. One cannot roam about as carefree as in joint family.' (Father, Futanwadi)

Participants felt that the joint family system was slowly giving way to a nuclear family system. The older generation feared this change and tended to blame their daughters-in-law:

'When a new daughter-in-law arrives, soon the house splits.' (Grandmother, Zodakwadi)

There is some evidence that a nuclear family structure may well be better for women and children. Santow's review of 
data from India and elsewhere showed that the nutritional status of children was better in families where the mother was head or co-head of a nuclear household than it was in families where the mother was a daughter-in-law in a traditional extended household ${ }^{28}$.

\section{Responsibility for the family's bealth and success}

Young women felt a strong sense of responsibility for their household's health and improvement. This manifested itself in two ways, both of which may impact on their nutritional status. First, young women appeared to worry excessively; second, they fasted regularly.

They worried about household chores, the children's health and future, crop failure and unpaid debts:

'The worries are all carried by the women. One has to do house and farm work.'

Moderator: 'Don't men have worries?'

'Men can discuss it with their friends.'

It is like, right now, I am sitting here in this discussion. But at the back of my mind I am worrying about when to start cooking, which vegetables to make for dinner, when will my children and husband eat? Whereas my husband is still with his friends gossiping away.'

'One has to always be doing something, like cleaning utensils, thinking what is to be cooked tomorrow morning.' (Mothers, Bargadwasti)

The men were aware of how much their women worried and described how their worrying drove the women to work harder:

'Women do a lot of work. They are always competing with [each] other to do better on the farm. They compete by working harder and harder for a better crop, to have a better return.'

Moderator: 'Do the men not have worries?'

'Men do have tension but they don't take it so seriously and try to live with it.'

'The wife sometimes ends up doing her husband's work as well.'

'She worries about the loans and debts of the family.' (Fathers, Pimplewadi)

Some felt that these worries were part of the reason for women's thinness and ill health. Both men and women suggested that men were better able to resolve their worries because they were able to talk things through with their friends. The women seemed more socially isolated. A woman living in the study villages has limited opportunities to meet other women and make friends because she never goes anywhere except to the farm and back, and works too hard to have time or energy for making friends. Coupled with this, the women appeared more ambitious for the future of their families than the men.
When asked how they thought the worries of young women could be reduced, one of the mothers suggested that if they could get regular paid work then they might worry less:

'If we get work every day, then what is there to worry about?' (Mother, Bhorshet)

Fasting was another expression by the women of their concern for the health and improvement of their families. Fasting by young women was the norm and was enforced by the neighbourhood women:

'Women keep fasts in praise of the God and Goddess, for the betterment of the family, so that the children grow up well, and for the health of their sons. Usually married women keep fasts and unmarried do not.' (Mother, Bhorshet)

Fasting was also a way in which a young bride could show she was trying to please her new family. Young women reported fasting for two days a week on average. By fasting and pleasing the gods, she was being dutiful and was bringing good luck to the family, luck that may help her give her in-laws a grandchild.

Fasts in this area were days when eating was limited to one meal a day. In houses where there was plenty, a variety of fasting foods were available including groundnuts, $k h i c h d i^{*}$, fruits and potato crisps. In poorer homes, women were limited to drinking tea on fasting days. Men and women both kept fasts although the primary responsibility for fasting rested with the women. Some men clearly fasted in name only:

'Fasting is in name only, as men keep eating a variety of things on a fasting day.' (Father, Pimplewadi)

'The difference is that on a fasting day, men go to the village where they can eat chirvat and tea. But the woman stays at bome therefore she does not eat anything extra.' (Father,

Futanwadi)

There is a clear expectation that young women fast more regularly and more strictly than men and others in the household. The tradition of fasting is rooted in Hinduism, which promotes self-sacrifice in women as a way of pleasing the gods and goddesses, and preventing bad luck. In India, men and women fast not only for religious reasons, but also as a social ritual and for the perceived health benefits.

The grandmothers and the young mothers both felt that today's young women fasted more often than in the past. When asked why, the grandmothers said it was because fasting had become easier and was now an attractive option:

*Khichdi as eaten here is a fasting food made from sago and potato. tChirva is a fasting snack made from flaked rice, gram dal and groundnuts. 
'Nowadays, young women can eat khichdi and tea, so they like it and do more fasting.' (Grandmother, Pimplewadi)

This might be true in the wealthier households where there is a variety of fasting foods, but does not coincide with the description of the situation for poorer women who were only able to drink tea on fasting days. This would invariably be tea without sugar. The exact implications of fasting for women's nutritional status are unknown, but at the very least it would reduce the variety of foods consumed and hence the micronutrient intake in a population already known to have limited micronutrient stores ${ }^{8}$.

Throughout her life, an Indian village woman is dependent on her men for social and economic security. She has, therefore, an interest in ensuring their continuing health and welfare. She is taught that one way of doing this is through fasting. In her investigation of food distribution within families in South Asia, Harriss explained that there are strong gender differences in fasting. Men fast for their own individual spiritual purposes, whereas women fast for the benefit of the whole household ${ }^{33}$. However, her analysis identified the older woman in the household to be the person most responsible for fasting for the family, while in our part of India this was the daughter-in-law's responsibility.

Young women in the study were in the uniquely stressful situation where they felt responsible for the family's health and welfare, but had no control over factors that might affect these things. They were excluded from decision-making about farming and financial matters and unable to choose what was bought at the market and hence fed to the family. The only ways in which women could exert influence were by fasting, to make sure the family was spiritually healthy, and by working harder. Both these responses are likely to contribute to young women's thinness.

\section{Conclusions and recommendations}

The focus group discussions identified four reasons for the relative thinness of women in this rural community. In addition to confirming some of what is already known about the lives of young rural women, we present novel observations about the excessive workload newly married young women carry and about their fasting practices. These features of the lives of young women are all but undocumented in the existing literature.

The discussions clearly identified the first year of marriage for a young women in a rural community as a time of increased physical work and reduced food intake, largely through shyness and fasting. Given these demands, bearing a child during this time is likely to compromise her nutritional status. Young women in this region may often still be growing at the age at which they get married. Their own need for nutrients may compete with the needs of the growing foetus, affecting their ability to nourish themselves and their babies ${ }^{34-36}$
Underlying all the discussions was the sense that immutable social structures conspired to make women in these villages thin. Participants were distressed to be told that women in their villages were thinner than they should be, but they understood and were able to articulate why this might be. They felt that life was too hard for women in rural areas and that the combined demands of farm work, domestic work and early marriage and motherhood were the likely cause of women's thinness.

We found no evidence of explicit gender discrimination. Participants loved and cared for their daughters. They expressed outrage at the suggestion that health care might not be sought for daughters when they became ill, but did concede that it might not be their first priority. Participants were keen to buy more comfortable lives for their daughters, to the point where they were prepared to take loans to pay for marrying their daughters to grooms who were employed outside farming. The lives of women who had to do farm work on top of their household duties were recognised to be particularly strenuous. The men, like the women, seemed to be trapped by a set of societal norms into a lifestyle that undermined the health and nutrition of their women.

The women suggested that if they had paid, regular jobs much of their anxiety would be alleviated. However, this is unlikely to be the whole answer. There is almost no correlation between income per head and gender disparities in health and education in countries across South Asia ${ }^{10}$. Gender disparity is not simply a problem of poverty. Neither is education on its own the key to improving the lot of women in India. Better-educated women have recently been found to be more likely to use sex-selective abortion to ensure that they have a son ${ }^{37}$. An examination of the literature suggests that the key lies in women having autonomy. Those areas or regions of South Asia where women are judged to have more control over their own lives, say in family decision-making, freedom of movement and access to material resources and information, are the states with the best outcomes for maternal and child health ${ }^{10,16,31}$. The young women in our focus group discussions expressed a preference for living in nuclear family units for the reason that it gave them more autonomy.

A common target for health interventions is to delay first conception. A woman is more likely to have a healthy baby once she is out of her teens and has stopped growing. The longer she lives with her in-laws, the more comfortable and confident of her place in the family she will become. The longer she delays the birth of her first baby, the better placed she is to play a part in decisions made about the child. Our focus group discussions confirmed that men are the decision-makers in the household in this part of India. Although family planning has in the past been considered an issue for women, it makes good sense to involve the husbands. Santow argues that targeting husbands in health and nutrition interven- 
tions brings them into areas that are usually the natural preserve of women and may alter the balance of power in the marital relationship to become more collaborative, and issues to do with treatment for their children become matters to be decided on together ${ }^{28}$. Through their alliance with a more powerful family member, women may be able to exert more control over family matters including those to do with her own fertility. The younger men in the focus groups were concerned about the health and welfare of their wives. This suggests that they would be supportive of attempts to improve their wives' nutritional status.

The social isolation of newly married young women in this area was obvious. One way to combat this might be through support groups for newly married women. Osrin et al. describe a community-based action research project intended to improve perinatal care in rural communities in $\mathrm{Nepal}^{38}$. They employed female facilitators to run women's groups, discussed the problems, shared experiences and planned action to improve maternal and newborn care. Despite involving less than half the target group of women, the effect was to reduce dramatically maternal and infant deaths ${ }^{39}$. Those who ran the study attribute its success to the facts that the women themselves decided what needed to be done and to the informal communication networks that the group established. Community-based nutrition interventions that genuinely involve local women in the decision-making process have been shown to be successful in improving the micronutrient status of their target populations ${ }^{40}$.

\section{Acknowledgements}

We thank our participants and their family members who took part in the project and the staff of King Edward Memorial Hospital, Pune, India. We are especially grateful for the help and support of Dr Shoba Rao and Dr Ranjan Yajnik. We would also like to thank Stephanie Lemke for her most helpful and detailed comments on earlier drafts of this paper.

\section{References}

1 United Nations Children's Fund (UNICEF). The State of the World's Children 2001 - Early Childhood. New York: UNICEF, 2001.

2 Ashworth A. Effects of intrauterine growth retardation on mortality and morbidity in infants and young children. European Journal of Clinical Nutrition 1998; 52(Suppl. 1): S34-42.

3 Barker DJP. Mothers, Babies and Health in Later Life, 2nd ed. London: Churchill Livingstone, 1998.

4 Kramer MS. Determinants of low birth weight: methodological assessment and meta-analysis. Bulletin of the World Health Organization 1987; 65(5): 663-737.

5 World Health Organization. Maternal anthropometry and pregnancy outcomes - a WHO collaborative study. Bulletin of the World Health Organization 1995; 73(Suppl.).

6 Yajnik CS, Fall CH, Hirve SS, Rao S, Barker DJ, Joglekar C, et al. Neonatal anthropometry: the thin-fat Indian baby. The Pune
Maternal Nutrition Study. International Journal of Obesity and Related Metabolic Disorders 2003; 27(2): 173-80.

7 Fall CHD, Yajnik CS, Rao S, Coyaji KJ, Shier RP. The effects of maternal body composition before birth on fetal growth: the Pune Maternal Nutrition and Fetal Growth Study. In: O'Brien PMS, Wheeler T, Barker DJP, eds. Fetal Programming: Influences on Development and Disease in Later Life. London: RCOG Press, 1999; 231-42.

8 Rao S, Yajnik CS, Kanade A, Fall CHD, Margetts B, Jackson $\mathrm{AA}$, et al. Intake of micronutrient-rich foods in rural Indian mothers is associated with the size of their babies at birth: the Pune Maternal Nutrition Study. Journal of Nutrition 2001; 131(4): $1217-24$

9 Miller BD. The Endangered Sex: Neglect of Female Children in Rural North India, 2nd ed. Delhi: Oxford University Press, 1996.

10 Filmer D, King EM, Pritchett L. Gender Disparity in South Asia: Comparisons Between and Within Countries. World Bank Policy Research Working Paper No. 1867. New York: World Bank, 1998.

11 Sharma DC. Widespread concern over India's missing girls. Lancet 2003; 362(8): 1553.

12 Ghosh S. Life cycle of maternal health, child health and survival. In: Puri RK, Sachdev HPS, Choudhury P, Verma IC, eds. Current Concepts in Pediatrics. New Delhi: Jaypee Brothers Medical Publishers, 1994; 43-58.

13 International Institute for Population Sciences. National Family Health Survey. Mumbai: International Institute for Population Sciences, 1995.

14 Pandey A, Sengupta PG, Mondal SK, Gupta DN, Manna B, Ghosh S, et al. Gender differences in healthcare-seeking during common illnesses in a rural community of West Bengal, India. Journal of Health, Population, and Nutrition 2002; 20(4): 306-11.

15 Arnold F, Choe MK, Roy TK. Son preference, the familybuilding process and child mortality in India. Population Studies 1998; 52: 301-15.

16 Pande RP, Yazbeck AS. What's in a country's average? Wealth, gender, and regional inequalities in immunization in India. Social Science \& Medicine 2003; 57(11): 2075-88.

17 Gittelsohn J. Opening the box: intrahousehold food allocation in rural Nepal. Social Science \& Medicine 1991; 33(10): $1141-54$.

18 Batliwala S. Rural energy scarcity and nutrition: a new perspective. Economic and Political Weekly 1982; 17(9): $329-33$.

19 Jejeebhoy SJ. Women's autonomy in India and Pakistan: the influence of religion and region. Population and Development Review 2001; 27(4): 687-712.

20 Millward L. Focus groups. In: Breakwell GM, Hammond S, Fife-Shaw C, eds. Research Methods in Psychology. London: Sage, 1995; 274-92.

21 Miles MB, Huberman MA. Qualitative Data Analysis: An Expanded Source Book, 2nd ed. Thousand Oaks, CA: Sage Publications Inc., 1994.

22 Tambiah SJ. Bride wealth and dowry revisited: the position of women in sub-saharan Africa and North India. Current Anthropology 1989; 30: 413-35.

23 Mukhopadhya A. Girl child in three Indian states. Economic and Political Weekly 1994: (4 June): 1379-82.

24 Ramanamma A, Bambawale U. The mania for sons: an analysis of social values in South Asia. Social Science \& Medicine 1980; 14(2): 107-10.

25 Rao S, Kanade A, Margetts BM, Yajnik CS, Lubree H, Rege S, et al. Maternal activity in relation to birth size in rural India. The Pune Maternal Nutrition Study. European Journal of Clinical Nutrition 2003; 57(4): 531-42.

26 United Nations (UN). The World's Women: Trends and 
Statistics. New York: UN Department of Economic and Social Information and Policy Analysis, 1995.

27 Jeffrey P, Jeffrey R, Lyon A. Labour Pains and Labour Power: Women and Childbearing in India, 1st ed. London: Zed Books Ltd, 1989

28 Santow G. Social roles and physical health: the case of female disadvantage in poor countries. Social Science $\mathcal{E}$ Medicine 1995; 40(2): 147-61.

29 Das Gupta M. Life course perspectives on women's autonomy and health outcomes. American Anthropologist 1995; 97(3): 481-91.

30 Basu AM. Cultural influences on health care use: two regional groups in India. Studies in Family Planning 1990; 21(5): 275-86

31 Bloom S, Wypij D, Das Gupta M. Dimensions of women's autonomy and the influence on maternal health care utilization in a north Indian city. Demography 2001; 38(1): 67-78.

32 Barua A, Kurz K. Reproductive health-seeking by married adolescent girls in Maharashtra, India. Reproductive Health Matters 2001; 9(17): 53-62.

33 Harriss B. The intrafamily distribution of hunger in South Asia. In: Drèze J, Sen A, Hussain A, eds. The Political Economy of Hunger. Oxford: Clarendon Press, 1995; 224-97.

34 World Health Organization (WHO). Multicentre Study on Low Birth Weight and Infant Mortality in India, Nepal and Sri Lanka. SEARO Regional Health Paper No. 25. Geneva: WHO, 1994
35 Martorell R, Ramakrishnan DG, Schroeder DG, Melgar P, Neufeld L. Intrauterine growth retardation, body size, body composition and physical performance in adolescence. European Journal of Clinical Nutrition 1998; 52(Suppl. 1): S43-53.

36 McNeill G, Davidson L, Morrison DC, Crombie IK, Keighran J, Todman J. Nutrient intake in schoolchildren: some practical considerations. Proceedings of the Nutrition Society 1991; 50(1): 37-43.

37 Retherford RD, Roy TK. Factors affecting sex-selective abortion in India. National Family Health Survey Bulletin 2003; 17: 1-4

38 Osrin D, Mesko N, Shrestha BP, Shrestha D, Tamang S, Thapa $S$, et al. Implementing a community-based participatory intervention to improve essential newborn care in rural Nepal. Transactions of the Royal Society of Tropical Medicine and Hygiene 2003; 97(1): 18-21.

39 Manandhar DS, Osrin D, Shrestha BP, Mesko N, Morrison J, Tumbahangphe KM, et al. Effect of participatory intervention with women's groups on birth outcomes in Nepal: cluster-randomised controlled trial. Lancet 2004; 364(9438): 970-9.

40 Johnson-Welch C. Explaining nutrition outcomes of foodbased interventions through an analysis of women's decision making power. Ecology of Food and Nutrition 2002; 41 $21-34$ 